\title{
Chemical synthesis and biological evaluation of an antimicrobial peptide gonococcal growth inhibitor
}

John D. Wade ${ }^{\mathrm{a}, \mathrm{b}, \#}$, Feng Lin ${ }^{\mathrm{a}}$, Mohammed Akhter Hossain ${ }^{\mathrm{a}, \mathrm{b}}$ and Raymond M. Dawson ${ }^{\mathrm{c}}$

${ }^{\mathrm{a}}$ Florey Neuroscience Institutes, University of Melbourne, Victoria 3010, Australia, ${ }^{\mathrm{b}}$ School of Chemistry, University of Melbourne, Victoria 3010, Australia, ${ }^{\mathrm{c}}$ Defence Science \& Technology Organisation, 506 Lorimer Street, Fishermans Bend, Victoria 3207, Australia

${ }^{\#}$ Address for correspondence:

Professor John D. Wade

Florey Neuroscience Institutes

University of Melbourne

Victoria 3010

Australia

Phone: 61-3-83447285

Fax: 61-3-93475826

Email: john.wade@florey.edu.au 


\begin{abstract}
:
Gonoccal Growth Inhibitor 1 (GGI-1) is a 44-residue peptide with potent anti-Legionella activity. It has been isolated from Staphylococcus haemolyticus but, to date, its chemical synthesis has not been reported. Acquisition of this peptide via this means would enable a more detailed examination of its antimicrobial properties. However, its synthesis represents a significant challenge because of two predicted "difficult sequences" within the peptide. Its successful solid-phase assembly is reported in this paper, and was accomplished by use of simple palliative measures including the introduction of a single pseudo-proline isostere in order to counteract on-resin aggregation. The peptide had moderate antimicrobial activity against Escherichia coli but was inactive against another Gram-negative bacterium and two Gram-positive bacteria (Bacillus species). It had significant haemolytic activity, with a $\mathrm{H}_{50}$ (concentration of peptide that causes $50 \%$ haemolysis) of $20 \mu \mathrm{M}$ and $125 \mu \mathrm{M}$ for two blood samples from different donors. An alternative therapeutic index to that proposed for GGI-1 in a recent publication is proposed.
\end{abstract}

Key words: antimicrobial peptide, "difficult sequence”, haemolytic activity, gonococcal growth inhibitor 1 , solid phase peptide synthesis 


\section{Introduction}

Antimicrobial peptides (AMPs) are relatively short polypeptides (12-100 amino acids) that are positively charged (net charge of +2 to +9 ) and amphiphilic. They have been isolated from singlecelled microorganisms, insects and other invertebrates, plants, amphibians, birds, fish and mammals, including humans, where they represent a defence system against invading pathogenic bacteria. This defence system includes direct inhibition of bacterial and viral pathogens combined with stimulation of the immune system, and the functions of the AMPs extend to innate and adaptive immunity, including immuno-modulation, chemotaxis, inflammatory response and wound repair. AMPs are important because of their potential to provide an alternative therapy against bacterial infections to conventional antibiotics in an age of increasing occurrence of antibioticresistant bacteria. A challenge in advancing AMPs to clinical use is the separation of potent antimicrobial activity from the unwanted cytotoxicity on normal mammalian cells, including erythrocytes (Dawson and Liu 2008).

The Australian Defence Science \& Technology Organisation has an interest in medical countermeasures against bacteria that could be used in biological warfare or as bioterror agents, and has recently evaluated a number of antimicrobial peptides in this context (Dawson and Liu 2008; 2010; 2011; Dawson et al 2010; 2011). Recently, various peptides secreted by Staphylococci species were found to have potent anti-Legionella activity (Marchand et al 2011), and it was decided to assess their antimicrobial activity against other bacteria. Most are easily chemically synthesised by conventional solid phase techniques. However one, Gonococcal Growth Inhibitor 1 (GGI-1), a 44-residue peptide that was isolated from S. haemolyticus (Watson et al 1988), has not has its chemical synthesis reported to date, and presents a significant challenge due to long stretches of hydrophobic amino acids in the overall sequence, making it a recognized so-called "difficult 
sequence". We now report its efficient chemical synthesis, purification, antimicrobial properties and haemolytic activity.

\section{Materials and Methods}

\section{Materials}

Human red blood cells were obtained free of charge under a contract with the Australian Red Cross Blood Service (Melbourne, Australia). All reagents for the antimicrobial and haemolytic assays were obtained from Sigma-Aldrich (Sydney, Australia). All amino acid derivatives for the synthesis of GGI-1 were purchased from GL Biochem (Shanghai, China).

\section{Synthesis of GGI-1}

The peptide was assembled on an automated PerSeptive Bioystems Pioneer peptide syntheziser using the continuous flow Fmoc solid phase synthesis methodology as previously described (Bathgate et al 2006; Hossain et al 2008, 2010). The solid support was appropriately C-terminal amino amide-linked Fmoc-PAL-PEG-PS for the preparation of C-terminal peptide amides (Applied Biosystems, Australia), and HBTU-activated Fmoc-amino acids were used throughout. Amino acid side chain protection was afforded by the following: Arg, Pbf; Asn and Gln, Trt; Asp and Glu, O$\mathrm{Bu}^{\mathrm{t}}$; His, Trt; Lys, Boc; Ser and Thr, Bu${ }^{\mathrm{t}}$. No repeat couplings were carried out. $\mathrm{N}^{\alpha}$-Fmoc deprotection was with $20 \%$ piperidine in DMF. Assembly of GGI-1 (1-44) commenced on a 0.1 mmol scale using a 4-fold excess of activated amino acid and 60 min coupling times. The synthesis was programmed to pause at $\mathrm{Ile}^{28}$ and $\mathrm{Ala}^{14}$ at which stages one half of the peptide resin was removed from the synthesizer and separately reacted with a 2-fold excess of activated Fmoc-ValSer(psiMe,MePro)-OH for $4 \mathrm{hrs}$ and then returned to the automated instrument and the synthesis continued. After acylation and $\mathrm{N}^{\alpha}$-deprotection of the final residue, $\mathrm{Met}^{1}$, the peptide-resin was treated with acetic anhydride in DMF for 30 mins, washed and dried prior to cleavage from the 
solid support and simultaneous side chain deprotection by a 1.5 -h treatment of the GGI-1(1-44) peptide-resin with trifluoroacetic acid (TFA) in the presence of anisole and 2,2'-(ethylenedioxy)diethanethiol (95/3/2, v/v) with a few drops of triisopropylsilane (TIS). The resulting crude peptide (183 mg) was subjected to preparative reversed-phase high performance liquid chromatography (RP-HPLC) on a Vydac C4 column (Hesperia, USA) using a $1 \% / \mathrm{min}$ gradient of $\mathrm{CH}_{3} \mathrm{CN}$ in $0.1 \%$ aqueous TFA. The major peak was collected, and subsequent freeze-drying gave $21.6 \mathrm{mg}(11.8 \%)$ of highly purified GGI-1(1-44).

\section{Chemical characterization}

The purity of the synthetic peptides was assessed by analytical RP-HPLC on a Phenomenex C18 column (pore size $300 \AA$, particle size $5 \mu \mathrm{m}, 4.6$ x $250 \mathrm{~mm}$ ) using a gradient of acetonitrile in $0.1 \%$ aqueous trifluoroacetic acid. The product was confirmed by MALDI-TOF mass spectrometry using a Bruker Autoflex II instrument (Bremen, Germany) in the linear mode at $19.5 \mathrm{kV}$. The peptides were quantitated by amino acid analysis of a $24 \mathrm{~h}$ acid hydrolysate using Waters Accu-Tag chemistry together with a Shimadzu microbore RP-HPLC system.

\section{Antibacterial assays}

The procedure has been described in a previous publication (Dawson et al 2010). The bacteria used were Escherichia coli K91 BK, Burkholderia thailandensis, Bacillus globigii ATCC 9372 and Bacillus anthracis (Sterne strain 34F2) (Dawson et al 2010; 2011). Briefly, a $5 \mathrm{~mL}$ aliquot of sterile NZCYM growth medium was inoculated with a colony of test bacteria and was incubated overnight at $37^{\circ} \mathrm{C}$ with shaking at $200 \mathrm{rpm}$. A $1 \mathrm{~mL}$ aliquot was diluted 100 -fold with fresh media and was incubated for a further $1 \mathrm{~h}$ with shaking at $37^{\circ} \mathrm{C}$. Aliquots $(200 \mu \mathrm{L})$ of the bacterial suspension were added to $200 \mu \mathrm{L}$ aliquots of peptide in the wells of a sterile 48 -well cell culture plate that had been treated with $1 \mathrm{~mL}$ of $0.5 \%$ bovine serum albumin in phosphate-buffered saline (PBS) to block peptide-binding sites (Zelezetsky et al 2005) and washed twice with $1 \mathrm{~mL}$ of PBS. 
The plate was incubated at $30^{\circ} \mathrm{C}$ with shaking at $150 \mathrm{rpm}$ for $8 \mathrm{~h}$. Readings of absorbance at 600 $\mathrm{nm}$ to monitor bacterial growth were taken at hourly intervals using a Synergy HT Plate Reader (BioTek Instruments, Winooski, Vermont, U.S.A.). Control wells contained no peptide (positive control) or no bacteria (blank). All experiments were repeated on a different day.

\section{Haemolysis}

The procedure has been described in a previous publication (Dawson et al 2010). Briefly, serial $(1+1)$ dilutions of the peptide in PBS $(100 \mu \mathrm{L})$ were prepared in the wells of a Nunc Immuno 96microwell flat-bottom plate (Nunc A/S, Roskilde, Denmark). A $100 \mu \mathrm{L}$ aliquot of 2\% washed human red blood cells in PBS was added to each well and the plate was incubated for 30 min at $37^{\circ} \mathrm{C}$ at $100 \mathrm{rpm}$. The plate was then centrifuged at $1000 \times \mathrm{g}$ for $20 \mathrm{~min}$ in a Heraeus Multifuge $3 \mathrm{~S}-$ R centrifuge (DJB Labcare Ltd., Newport Pagnell, UK). Aliquots (100 $\mu$ L) of the well supernatants were transferred to a fresh 96-well plate and the absorbance at $414 \mathrm{~nm}$ was read in the plate reader as a measure of the release of haemoglobin. Controls (in triplicate) were $0.1 \%$ Triton X-100 in PBS (positive control) and PBS only (blank). Replicate experiments were performed with each of two separate samples of blood cells (i.e., different donors). The concentration of peptide that causes $50 \%$ haemolysis $\left(\mathrm{H}_{50}\right)$ was determined by fitting a second-order polynomial curve to the linear-log version of the (percent haemolysis)-concentration plot.

\section{Results and Discussion}

\section{Synthesis of GGI-1}

GGI-1 is a 44-residue, highly hydrophobic peptide that was reported to contain an N-terminal formyl-Met and free C-terminal carboxylate (Watson et al 1998). In order to further characterize its antimicrobial properties we undertook its chemical synthesis as an N-terminal acetylated and Cterminal peptide amide as the latter modification generally enhances structural stability and 
antimicrobial activity or decreases cytotoxicity (Kim et al 2011). A prior, default solid phase synthesis of GGI-1 using well-established in-house protocols that consistently produces good quality crude peptides of varying lengths and sequences in our laboratory was initially employed but was found to yield no identifiable target product (data not shown). Re-examination of the peptide sequence highlighted the presence of numerous hydrophobic and bulky residues with many in long stretches within GGI-1 indicating it was a so-called "difficult sequence" (Milton et al 1990). Such sequences are often refractory to chemical synthesis for any one of a number of reasons including on-resin aggregation. The phenomenon remains a subject of intense investigation with many palliative or, even, remedial measures proposed and demonstrated to be at least moderately effective (Tickler and Wade 2007; Abdel Rahman et al 2007). Indeed, GGI-1 sequence analysis by a software prediction program (Peptide Companion; Lebl et al 1995) suggested that two broad regions of significant synthetic difficulty could be expected, one within the C-terminal 20 residues and the other comprising the $\mathrm{N}$-terminal 10 residues (Fig. 2). For this reason, a repeat assembly was undertaken in which one-third of the way through the assembly, one-half of the peptide resin was removed to result in higher molar excesses of activated amino acid being used for the remainder of the synthesis. Then, later in the assembly and prior to the commencement of the N-terninal "difficult sequence" region, additional peptide-resin was removed and a single pseudo-Pro isostere was introduced in order to reduce or eliminate on-resin aggregation which is often associated with failed assemblies (Tickler et al 2007). At the end of the synthesis, not only was GGI-1 obtained but it was also in good quality making its subsequent purification in overall yield of $12 \%$ straightforward (Fig. 3). Such a result confirms earlier reports that seemingly modest alterations to synthetic schedules or protocols can have dramatic effects on the success of synthesis of "difficult sequences" (Tickler et al 2004). The use of pseudo-Pro isosteres is especially effective and their increased cost is far outweighed by the consistently positive outcomes that these confer on the acquisition of complex peptides (Mutter et al 1995; White et al 2004). 


\section{Antimicrobial activity}

GGI-1 failed to significantly inhibit growth of any of B. thailandensis, B. globigii and B. anthracis at concentrations up to $100 \mu \mathrm{M}$ (the highest concentration tested). Some (but not complete) inhibition of growth of $E$. coli was observed, and the $\mathrm{I}_{50}$ (the concentration that reduced net absorbance at $600 \mathrm{~nm}$ by $50 \%$ ) was found to be $71 \pm 10.6 \mu \mathrm{M}$ (s.e.m.; n = 2). In simultaneous experiments, tetracycline had a minimum inhibitory concentration (MIC) of $65 \pm 0 \mu \mathrm{M}$ and an $\mathrm{I}_{50}$ of $13.6 \pm 1.5 \mu \mathrm{M}$.

GGI-1 has been reported to have a MIC against Legionella pneumophila of $4.2 \mu \mathrm{M}$ (Marchand et al 2011). This appears to be the only quantitative report of the antibacterial activity of GGI-1, as descriptions of its inhibitory properties against growth of Neisseria gonorrhoeae (Marchand et al 2011; Beaudet et al 1982) are qualitative only.

\section{Haemolytic activity}

The only report of haemolytic activity of GGI-1 quotes the factor $\mathrm{H}_{10}$, which is the concentration that causes $10 \%$ haemolysis of human erythrocytes. This was found to be $2.1 \mu \mathrm{M}$ (Marchand et al 2011). We have determined the full spectrum of haemolytic activity as a function of peptide concentration, and this is shown in Fig. 3. Results for blood from each of two donors are shown, rather than overall mean values, because of the substantial variation of values between the two samples. Values of $\mathrm{H}_{50}$ (concentration of peptide that causes $50 \%$ haemolysis) were found to be $19.6 \mu \mathrm{M}$ and approximately $125 \mu \mathrm{M}$ for the two blood samples respectively. A value of $\mathrm{H}_{10}$ could not be determined for one of the blood samples, since haemolysis was over $20 \%$ at the lowest concentration tested $\left(0.39 \mu \mathrm{M}\right.$; Fig. 3). For the other blood sample, $\mathrm{H}_{10}$ is approximately $0.5 \mu \mathrm{M}$. This value is consistent with the literature value of $\mathrm{H}_{10}(2.1 \mu \mathrm{M}$, above), given the variability in results with blood from different donors (Fig. 3). These results suggest that the value of $\mathrm{H}_{10}$ is not a reliable indicator of haemolytic activity. Thus, although one blood sample had $\mathrm{H}_{10} \sim 0.5 \mu \mathrm{M}$ for 
GGI-1, a concentration 200 times higher than this $(100 \mu \mathrm{M})$ failed to achieve even $50 \%$ haemolysis, let alone $100 \%$. Marchand et al (2011) calculated a therapeutic index for various peptides, which they defined as $\mathrm{H}_{10} / \mathrm{MIC}$. This index of selectivity was found to be 0.5 for GGI-1. We propose that $\mathrm{H}_{50} / \mathrm{I}_{50}$ is a better definition of the therapeutic index, since both haemolytic and antibacterial activity are expressed in terms of $50 \%$ efficacy (Dawson et al 2011). Our determination of $\mathrm{H}_{50}$ for GGI-1 (20-125 $\mu \mathrm{M})$ suggests that the refined therapeutic index for GGI-1 in the systems of Marchand et al (2011) would be of the order of 20-125 (since the I50 of GGI-1 vs L. pneumophila appears to be approx. $1 \mu \mathrm{M}$ ), which puts its potential clinical application in an entirely different light from that with a therapeutic index of 0.5 based on use of the value of $\mathrm{H}_{10}$.

\section{Conclusion}

Increasing bacterial resistance is one of the world's most serious health concerns. It has been forecast that within 10 years, today's generation of antibiotics may be largely ineffective. The development of antimicrobial resistance is multi-faceted, but unanimous agreement amongst healthcare professionals and the pharmaceutical industry is the urgent need for new, potent and selective antimicrobial agents. Antimicrobial peptides (AMPs) have rapidly emerged as an important alternative to small molecule antibiotics due to their potency and varying modes of action. Numerous such peptides have been identified and subjected to detailed investigation but, thus far, few have been reported to possess potent, selective activity without cytotoxic effects. The identification of an antimicrobial gonoccal growth inhibitor-derived peptide, GGI-1, represents another source of potential antimicrobial therapy that necessitates detailed examination. Its acquisition was only achieved using modified solid phase synthesis protocols to overcome its "difficult sequence" resistance which highlights the continued importance this technology makes to such studies. The data showed that although the peptide lacks significant activity against common bacteria and possesses haemolytic activity that restricts its utility, chemical synthesis of may provide a means of obtaining designed analogues with improved activity spectrum. 


\section{Acknowledgements}

The authors are grateful to the Australian Red Cross Blood Service (Melbourne, Australia) for the gift of human erythrocytes. The studies at the FNI were supported by the Victorian Government's Operational Infrastructure Support Program.

\section{References}

Abel Rahman S, El-Kafrawy A, Hattaba A, Anwer MF (2007) Optimization of solid-phase synthesis of difficult peptide sequences via comparison between different improved approaches. Amino Acids 33:531-536

Bathgate RAD, Lin F, Hanson NF, Otvos Jr L, Guidolin A, Giannakis C, Bastiras S, Layfield S, Ferraro T, Ma S, Zhao C, Gundlach AL, Samuel CS, Tregear GW, Wade JD (2006) Relaxin-3: Improved synthesis strategy and demonstration of its high-affinity interaction with the relaxin receptor LGR7 both in vitro and in vivo. Biochemistry 45:1043-1053

Beaudet R, Bisaillon JG, Saheb SA, Sylvestre M (1982). Production, purification, and preliminary characterization of a gonococcal growth inhibitor produced by a coagulase-negative staphylococcus isolated from the urogenital flora. Antimicrob Agents Chemother 22:277-283

Dawson RM, Liu CQ (2008) Properties and applications of antimicrobial peptides in biodefense against biological warfare threat agents. Crit Rev Microbiol 34:89-107 
Dawson RM, Liu CQ (2010) Disulphide bonds of the peptide protegrin-1 are not essential for antimicrobial activity and haemolytic activity. Int J Antimicrob Agents 36:579-580

Dawson RM, McAllister J, Liu CQ (2010) Characterisation and evaluation of synthetic antimicrobial peptides against Bacillus globigii, Bacillus anthracis and Burkholderia thailandensis. Int J Antimicrob Agents 36:359-363

Dawson RM, Liu CQ (2011) Analogues of peptide SMAP-29 with comparable antimicrobial potency and reduced cytotoxicity. Int J Antimicrob Agents 37:432-437

Dawson RM, Fox MA, Atkins HS, Liu CQ (2011) Potent antimicrobial peptides with selectivity for Bacillus anthracis over human erythrocytes. Int J Antimicrob Agents 38:237-242

Hossain MA, Bathgate RA, Kong C, Shabanpoor F, Zhang S, Haugaard-Jönsson LM, Rosengren KJ, Tregear GW, Wade JD (2008) Synthesis, conformation and receptor binding activity of human insulin-like peptide 5 (INSL5). ChemBioChem 9:1816-1822

Hossain MA, Samuel CS, Binder C, Hewitson TD, Tregear GW, Wade JD, Bathgate RA (2010) The chemically synthesized human relaxin-2 analog, B-R13/17K H2, is an RXFP1 antagonist. Amino Acids 39:409-416

Kim J-Y, Park S-C, Hahm K-S, Park Y (2011) C-terminal amidation of PMAP-23: translocation to the inner membrane of Gram-negative bacteria. Amino Acids 40:183-195

Lebl M, Krchnak V, Lebl G (1995) Peptide Companion, San Diego, CA. http://www.5z.com/psp/software.shtml. 
Marchand A, Verdon J, Lacombe C, Crapart S, Héchard Y, Berjeaud JM (2011) Anti-Legionella activity of staphylococcal hemolytic peptides. Peptides 32:845-851

Milton RC, Milton SCF, Adams PA (1990) Prediction of difficult sequences in solid-phase peptide synthesis. J Am Chem Soc 112:6039-6046

Mutter M, Nefzi A, Sato T, Sun X, Wahl F, Wöhr T (1995) Pseudo-prolines (psi Pro) for accessing "inaccessible" peptides. Pept Res 8:145-153

Tickler AK, Clippingdale AB, Wade JD (2004) Amyloid- $\beta$ as a "difficult sequence" in solid phase peptide synthesis. Protein Pept Lett 11:377-384

Tickler AK, Wade JD (2007) Solid phase synthesis of “difficult” peptide sequences. In: Coligan JE, Dunn BM, Speicher DW, Wingfield PT (eds.) Current protocols in protein science, John Wiley \& Sons, New York. Vol. 50, Unit 18.8, pp.1-6, 2007

Watson DC, Yaguchi M, Bisaillon JG, Beaudet R, Morosoli R (1988) The amino acid sequence of a gonococcal growth inhibitor from Staphylococcus haemolyticus. Biochem J 252:87-93

White P, Keyte JW, Bailey K, Bloomberg G (2004) Expediting the Fmoc solid phase synthesis of long peptides through the application of dimethyloxazolidine dipeptides J Pept Sci 10:18-26

Zelezetsky I, Pag U, Antcheva N, Sahl H-G, Tossi A (2005) Identification and optimization of an antimicrobial peptide from the ant venom toxin pilosulin. Arch Biochem Biophys 434:358-364 
FIGURE LEGENDS:

Figure 1. Primary structure of GGI-I.

Figure 2. Aggregation and corresponding synthetic difficulty of GGI-1 as predicted by "Peptide Companion". Aggregation potential greater than 1.2 is indicative of amino acid acylation difficulty.

Figure 3. A. Analytical RP-HPLC of purified synthetic GGI-I on a Vydac C4 column (4.6 x 250 mm). Buffer A: $0.1 \%$ aqueous TFA; Buffer B: $0.1 \%$ TFA in $\mathrm{CH}_{3} \mathrm{CN}$. Gradient: $20-100 \%$ B in 30 mins. Wavelength: $214 \mathrm{~nm}$; Flow rate: $1.5 \mathrm{ml} / \mathrm{min}$. Column temperature: $50^{\circ} \mathrm{C}$. B. MALDI-TOF mass spectrum of purified synthetic GGI-I (calcd. [MH+] 4564.39, found [MH+] 4563.90).

Figure 4. Haemolytic activity of GGI-1. 
Figure 1.

Ac-MQKLAEAIAAAVSAGQDKDWGKMGTSIVGIVENGITVLGKIFGF-CONH 2

$\begin{array}{lllllllll}1 & 5 & 10 & 15 & 20 & 25 & 30 & 35 & 40\end{array}$


Figure 2

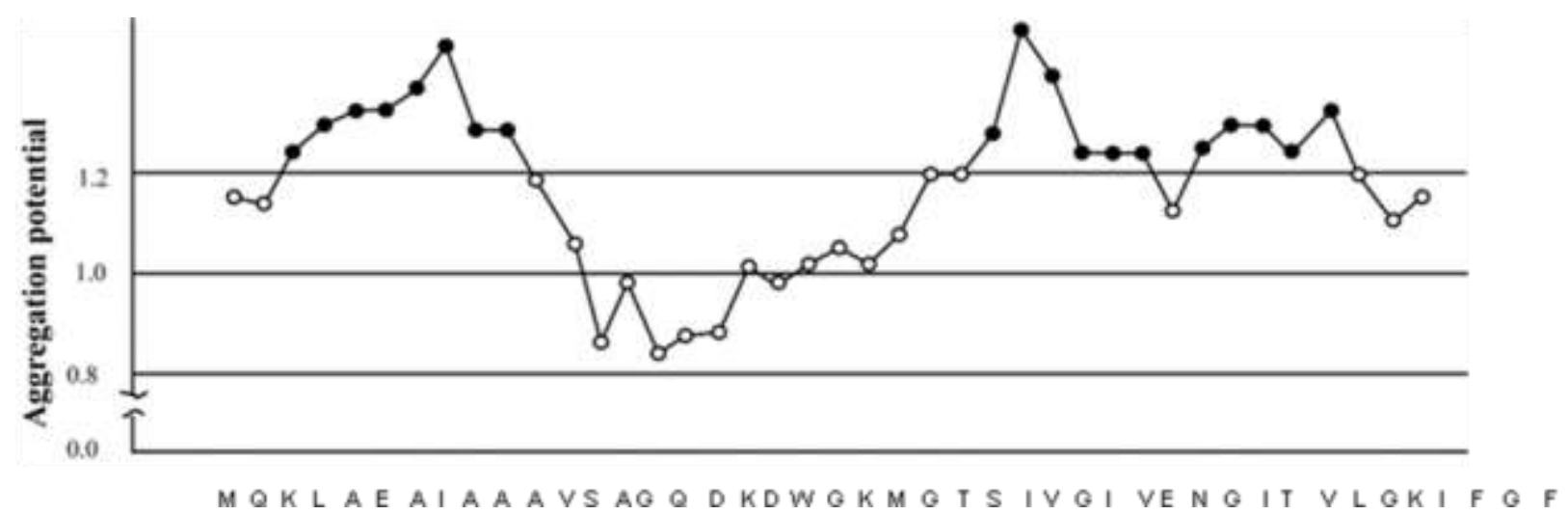


Figure 3
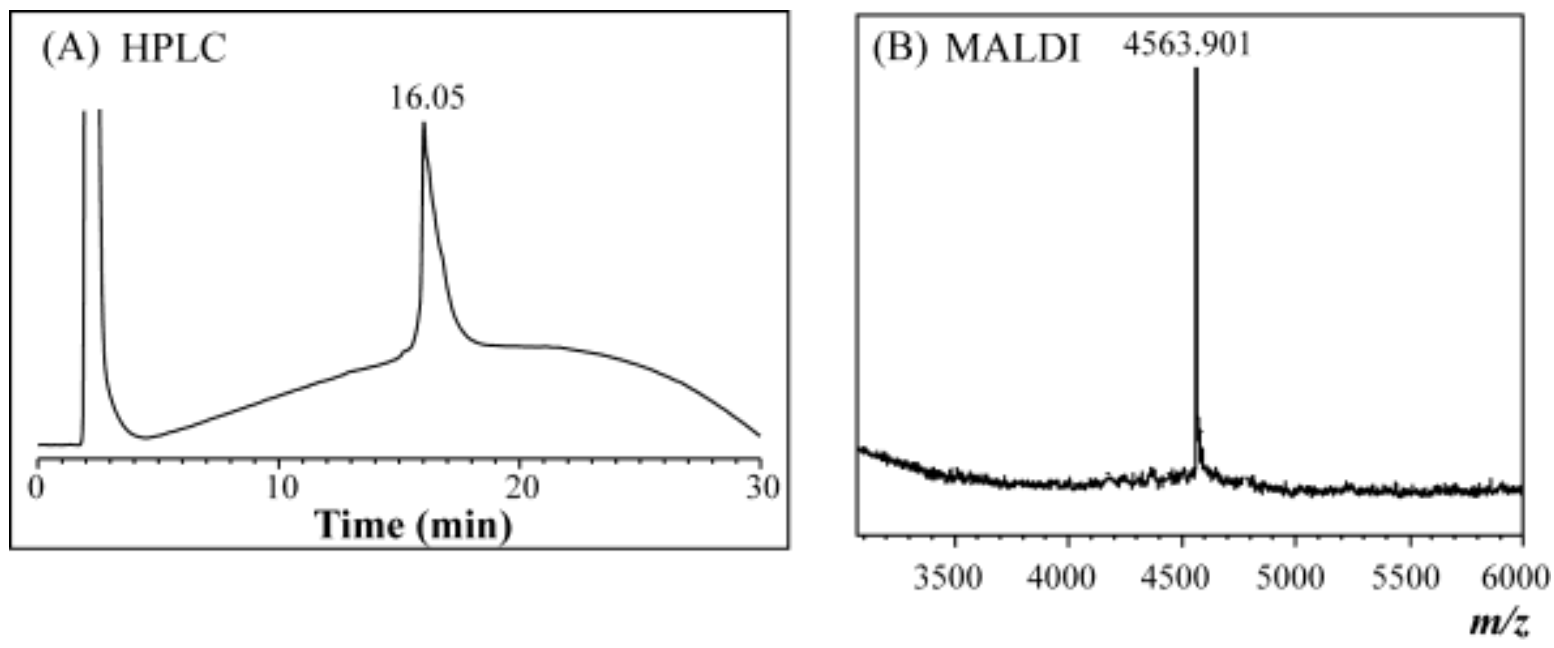
Figure 4

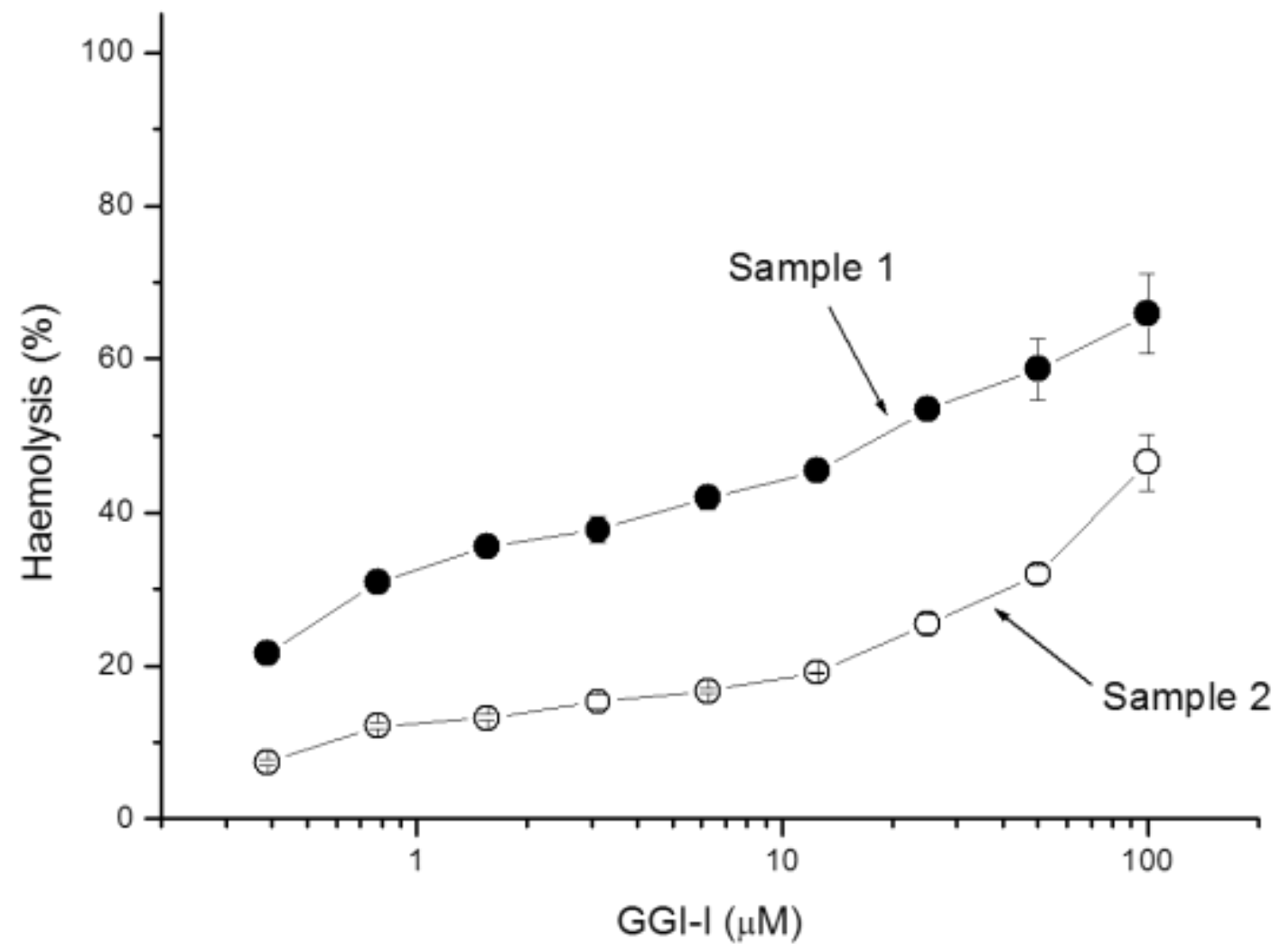

